ISSN : 2303-1514 | E-ISSN : 2598-5949

\title{
EFFORTS TO IMPROVE STUDENTS' LONG JUMP ABILITY THROUGH RESISTANCE ROPE MEDIA AT GRADE V OF SDN 17 MANDAU
}

\author{
Berliana Barutu \\ SDN 17 Mandau, Bengkalis, Indonesia \\ berlianabarutu@gmail.com

\section{UPAYA MENINGKATKAN KEMAMPUAN LOMPAT JAUH SISWA KELAS V SDN 17 MANDAU MELALUI MEDIA TALI RINTANGAN}

\begin{tabular}{ll}
\hline \multicolumn{1}{c}{ ARTICLE HISTORY } & \multicolumn{1}{c}{ ABSTRACT } \\
\cline { 2 - 3 } & $\begin{array}{l}\text { Abstract: The background of this research was the students' low ability in performing long } \\
\text { jump squat style. Thus, the researchers tried to take action in order to increase students' } \\
\text { ability. The effort was using resistance rope learning media. This research was a classroom } \\
\text { action research conducted on } 23 \text { students in class VB. The implementation of this research was } \\
\text { in the odd semester of the } 2019-2020 \text { school year. The research instrument was the student's } \\
\text { long jump ability observation sheet. The results of the research in the first cycle obtained } \\
\text { classical completeness as many as } 17 \text { students or } 73.91 \% \text { and increased to } 86.95 \% \text { with the } \\
\text { number of students who completed as many as } 20 \text { people. Based on the results of the study, it } \\
\text { was concluded that the students' ability to perform the long jump squat style increased through } \\
\text { the use of resistance rope media. }\end{array}$ \\
& Keywords: long jump ability, rope media
\end{tabular}

Accepted:

04 Agustus 2021

$04^{\text {th }}$ August 2021

Published: 27 Agustus 2021 $27^{\text {th }}$ August 2021
Abstrak: Penelitian ini dilatarbelakangi oleh rendahnya kemampuan siswa dalam melakukan lompat jauh gaya jongkok. Sehingga peneliti berupaya melakukan tindakan agar kemampuan siswa menjadi lebih baik dan mengalami peningkatan, upaya yang dilakukan adalah dengan menggunakan media pembelajaran tali rintangan. Penelitian ini merupakan penelitian tindakan kelas yang dilakukan pada siswa kelas VB yang berjumlah 23 siswa. Pelaksanaan penelitian ini pada semester ganjil tahun ajaran 2019-2020. Instrumen penelitian yang digunakan adalah lembar observasi kemampuan lompat jauh siswa. Hasil penelitian pada siklus I memperoleh ketuntasan secara klasikal sebanyak 17 siswa atau sebesar $73.91 \%$ kemudian mengalami peningkatan menjadi $86.95 \%$ dengan jumlah siswa yang tuntas sebanyak 20 orang. Berdasarkan hasil penelitian dapat disimpulkan bahwa kemampuan siswa dalam melakukan lompat jauh gaya jongkok dapat mengalami peningkatan melalui penggunaan media tali rintangan.

Kata Kunci: kemampuan lompat jauh, media tali rintangan

\section{CITATION}

Barutu, B. (2021). Efforts to Improve Students' Long Jump Ability through Resistance Rope Media at Grade V of SDN 17 Mandau. Primary: Jurnal Pendidikan Guru Sekolah Dasar, 10 (4), 1062-1068. DOI: http://dx.doi.org/10.33578/jpfkip.v10i4.8431.

\section{PENDAHULUAN}

Pembelajaran pendidikan jasmani, olahraga, dan kesehatan (penjasorkes) merupakan kegiatan pembelajaran yang menekankan pada aktifitas gerak dan jasmani serta usaha sadar melalui pendidikan untuk merangsang tumbuh kembang siswa agar tampil sebagai insan yang sehat baik dalam tindakan, tingkah laku, pikiran, dan mental.
Melalui pendidikan jasmani manusia dapat belajar lebih banyak hal yang berhubungan dengan kognitif, psikomotorik, dan afektif yang merupakan bekal manusia mencapai tujuan hidup (Hanief, 2015). Pendidikan jasmani, olahraga, dan kesehatan bertujuan untuk mengembangkan keterampilan gerak. Gerak terbagi dalam 3 kategori yakni: lokomotor, non lokomotor, dan manipulasi. 


\section{PRIMARY: JURNAL PENDIDIKAN GURU SEKOLAH DASAR \\ VOLUME 10 NOMOR 4 AGUSTUS 2021 \\ ISSN : 2303-1514 | E-ISSN : 2598-5949 \\ DOI : http://dx.doi.org/10.33578/jpfkip.v10i4.8431 \\ https://primary.ejournal.unri.ac.id/index.php/JPFKIP}

Dalam pembelajaran penjasorkes kita sering mendengar istilah atletik, atletik ini dikenal sebagai induk dari cabang olah raga. Atletik merupakan gerak dasar alamiah manusia seperti berjalan, berlari, melompat, dan melempar. Dalam melompat ada beberapa jenis diantaranya lompat jangkit (triple jump), lompat tinggi (high jump), lompat galah (pole vault), dan lompat jauh (long jump) (Azhar, 2015).

Pembelajaran penjasorkes tidak hanya dilakukan di dalam ruangan kelas, melainkan juga lebih baik dengan adanya praktik di lapangan. Dalam praktik di lapangan sering kali didapati pembelajaran yang kurang efektif. Pada materi lompat jauh, teknik dasar yang paling sulit untuk dipahami siswa untuk mempraktikkannya dengan tepat adalah teknik bertumpu, cara melakukan awalan, sikap badan saat melayang di udara, dan cara melakukan pendaratan. Siswa kadang kesulitan untuk menempatkan kakinya pada balok tumpuan saat akan melakukan tolakan, pada saat di udara tidak berupaya melakukan dorongan dengan meluruskan tangan dan kaki ke depan, dan saat mendarat masih banyak yang tidak tepat sehingga banyak yang terjatuh.

Hal ini diperkuat dengan hasil wawancara yang dilakukan terhadap siswa, dari 23 siswa hanya 10 orang siswa yang paham mengenai teknik bertumpu. Dapat diketahui dari data tersebut sebesar $43.47 \%$ dari jumlah siswa belum memahami teknik bertumpu yang baik, sikap badan saat melayang di udara, dan pendaratan yang baik pada materi lompat jauh. Hasil ini tentu perlu ditingkatkan agar seluruh siswa memiliki pemahaman yang baik atau setidaknya sebesar $85 \%$ siswa dapat memahaminya dengan baik.

Berdasarkan dari hasil tersebut, diperlukan suatu cara agar siswa dapat menguasai gerakan lompat jauh dengan benar sehingga menghasilkan lompatan yang maksimal. Salahsatu upaya yang dapat dilakukan adalah dengan menggunakan media tali rintangan yang dapat mengembangkan daya otot tungkai yang dilakukan dengan loncat katak (jongkok), loncat naik turun bangku, latihan loncat antar kotak bertingkat, melompat dan melambung di atas serangkaian rintangan. Penelitian semacam ini sudah lebih dahulu dibuktikan oleh Hasibuan (2014).

\section{KAJIAN TEORETIS Lompat Jauh}

Melompat merupakan teknik yang mendasari kemampuan lompat jauh gaya jongkok yang harus dikuasai oleh siswa. Lompat jauh merupakan rangkaian gerakan yang diawali dengan lari cepat, menolak, melayang, dan mendarat. Seperti yang dikemukakan oleh Syarifuddin dalam Satriyo (2014) bahwa lompat jauh adalah suatu gerakan melompat mengangkat kaki ke atas ke depan dalam upaya membawa titik berat badan selama mungkin di udara (melayang di udara) yang dilakukan dengan cepat dan dengan jalan melalui tolakan pada suatu kaki untuk mencapai jarak sejauh-jauhnya. Menurut Yudha dalam Admojo (2018) bahwa lompat jauh merupakan keterampilan gerak berpindah dari satu tempat ke tempat lainnya dengan satu kali tolakan ke depan sejauh mungkin.

Teknik dalam melakukan lompat jauh gaya jongkok adalah sebagai berikut (Haryono, 2018): 1) Siswa berbaris sejajar di depan bak lompat sejauh 5 meter; 2) satu persatu siswa melakukan ancang-ancang atau awalan, awalan dilakukan dengan berlari secepat-cepatnya menuju balok tumpuan; 3) setelah sampai pada balok tumpuan, siswa bertumpu pada salah satu kaki pada balok tumpuan dengan tepat. Kemudian melompat setinggi mungkin dan kaki yang satunya melangkah ke depan dengan posisi badan condong ke depan; 4) saat melayang, kedua lutut kaki ditekuk dan mendarat dengan posisi jongkok. Untuk lebih jelas dapat dilihat pada gambar 1 berikut: 


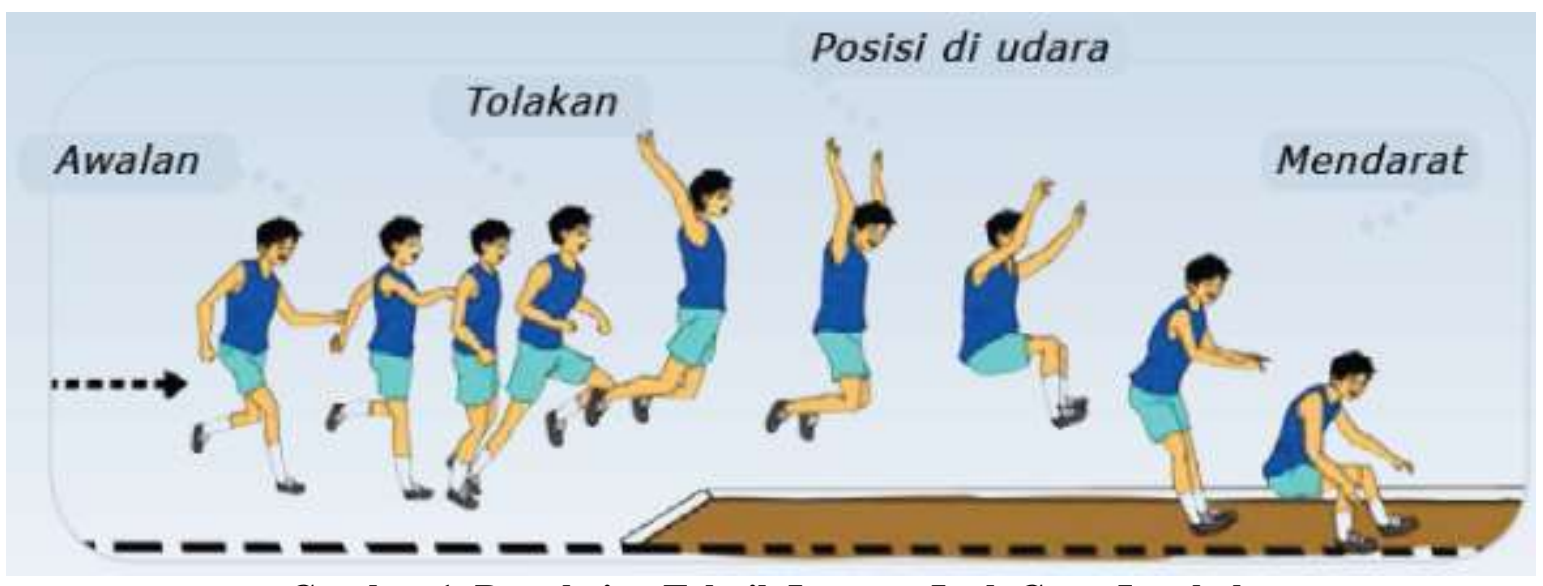

Gambar 1. Rangkaian Teknik Lompat Jauh Gaya Jongkok

\section{Media Tali Rintangan}

Upaya untuk meningkatkan daya ledak otot tungkai menurut Carr dalam Nur (2019) yakni dengan berlatih melompati rintangan. Dalam penelitian ini yang menjadi rintangan adalah tali yang terbuat dari karet gelang yang disambung sedemikian rupa kemudian diikat pada tiang kiri dan kanan sehingga membentang luas. Hal ini agar tali terikat dengan kuat tanpa berpindah-pindah.

Adapun peralatan dan perlengkapan lompat jauh terdiri dari: 1) pita pengukur, digunakan untuk mengukur jarak lompatan. Jarak lompatan diukur dari ujung terdekat papan pelepas ke ujung terdekat tempat pendaratan dalam kawasan pendaratan; 2) sepatu yang bergigi, agar dapat berlari dan mendarat dengan baik karena tidak mudah terpelesat serta memudahkan dalam membuat tanda pada saat mendarat; 3) bendera isyarat, untuk mengawasi lompatan. Terdapat 2 bendera yakni merah dan putih, merah untuk lompatan yang batal, dan putih untuk yang sah; 4) papan pelepas, digunakan sebagai tanda dan permulaan lompatan. Papan pelepas yang standar adalah (1) 2 buah tiang dengan tinggi $150 \mathrm{~cm}$ dan (2) tali rintangan dengan panjang 3 meter yang terbuat dari karet gelang.

\section{METODE PENELITIAN}

Penelitian ini merupakan penelitian tindakan kelas (PTK) atau classroom action research dengan demikian prosedur yang diterapkan adalah mengacu pada peneitian tindakan kelas yang pelaksanaannya berupa pengajaran atau pelatihan di kelas. Penelitian ini merupakan suatu penelitian yang bersifat reaktif dalam artian suatu tindakan dilakukan atas dasar keadaan yang ada pada suatu objek tertentu seperti siswa agar dapat memperbaiki atau meningkatkan praktik pembelajaran di kelas atau di sekolah secara lebih professional (Arikunto, 2014).

PTK memiliki ciri penelitian bersiklus yang setiap siklusnya memiliki tahapantahapan yang mesti dilalui oleh peneliti yang meliputi tahapan perencanaan (planning), tahapan tindakan (acting), tahapan pengamatan (observating), dan refleksi (reflecting) (Kasihani dalam Ridwan, 2020). Subjek penelitian ini adalah seluruh siswa kelas VB SDN 17 Mandau yang berjumlah 23 orang dengan laki-laki sebanyak 12 siswa dan perempuan 11 siswa. Pelaksanaan penelitian ini pada semester ganjil tahun ajaran 20192020.

Teknik pengumpulan data menggunakan teknik observasi dengan instrumen menggunakan lembar observasi kemampuan lompat jauh siswa. Siswa dinyatakan tuntas secara individu apabila mampu memperoleh nilai $\geq 70$. Nilai ketuntasan individu dapat dihitung dengan menggunakan rumus sebagai berikut (Ridwan, 2020):

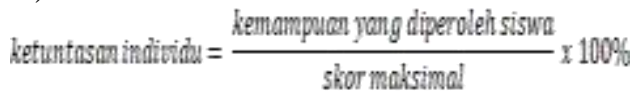


Secara klasikal, penelitian ini dianggap telah berhasil meningkatkan kemampuan siswa jika 85\% dari seluruh siswa mampu memperoleh nilai $\geq 70$, untuk menghitung ketuntasan klasikal dapat digunakan rumus sebagai berikut (Ridwan, 2020):

$$
\text { ketuntasan klasikal }=\frac{\text { jumlah siswa yang tuntas }}{\text { jumlah siswa yang ikut tes }} \times 100 \%
$$

\section{HASIL DAN PEMBAHASAN Hasil}

\section{Kondisi awal}

Sebelum melakukan tindakan, terlebih dahulu peneliti melakukan tes awal untuk melihat dan merumuskan masalah yang ditemukan dari hasil tes awal. Tes ini dilakukan dengan menguji lompat jauh siswa dengan media bak pasir atau lapangan di sekitar sekolah. Dari tes yang dilakukan ditemukan bahwa siswa yang mampu melakukan lompat jauh dengan baik hanya 10 orang dengan kata lain sebesar $43.47 \%$ dari 23 siswa yang memiliki kemampuan lompat jauh yang baik, sisanya sebanyak 13 (56.52\%) orang masih perlu dilatih agar kemampuannya meningkat.

2. Siklus I

Untuk melihat kemampuan lompat jauh siswa, peneliti melakukan pengamatan terhadap unjuk kerja siswa selama proses kegiatan pembelajaran dilaksanakan. Selama pemantauan aktivitas belajar siswa berupa lompat jauh gaya jongkok, peneliti mencatat kemudian menganalisis setiap hasil yang diperoleh siswa. Adapun hasil pengamatan kemampuan siswa secara individu disajikan pada tabel berikut:

Tabel 1. Rekapitulasi Kemampuan Lompat Jauh Gaya Jongkok Siswa Siklus I

\begin{tabular}{ccc}
\hline Ketuntasan & Jumlah Siswa & Persentase \\
\hline Tuntas & 17 & $73.91 \%$ \\
Belum Tuntas & 6 & $26.08 \%$ \\
Jumlah & 23 & $100 \%$ \\
\hline
\end{tabular}

Berdasarkan tabel 1 di atas diketahui bahwa kemampuan siswa dalam melakukan lompat jauh gaya jongkok masih belum menghasilkan jumlah yang maksimal sesuai yang diharapkan. Dari seluruh siswa yang diberikan tindakan menggunakan media tali rintangan, terdapat 17 siswa atau sebesar $73.91 \%$ yang sudah memiliki kemampuan yang baik, namun masih ada 6 siswa $(26.08 \%)$ yang belum mencapai kemampuan yang diharapkan.

Kendati demikian, hasil dari siklus I sudah dapat dilihat adanya peningkatan daripada tes awal yang semula ketuntasan klasikal sebesar $43.47 \%$ menjadi $73.91 \%$ yang mampu melakukan lompat jauh dengan baik. Tindakan yang dilakukan sudah menunjukkan hasil yang positif namun tetap harus dilanjutkan karena masih belum mencapai indikator keberhasilan yang diharapkan. Untuk itu, agar memperoleh hasil dalam kemampuan lompat jauh yang lebih baik maka pada siklus selanjutnya dapat dilakukan beberapa perbaikan dengan catatan peneliti harus terus memberikan motivasi agar siswa selalu bersemangat untuk melakukan dengan maksimal, selain itu peneliti juga meminta agar siswa terus berlatih agar lebih terampil dan memiliki otot yang kuat sehingga dapat memberikan daya ledak yang kuat dalam melakukan lompatan. Dengan melatih daya ledak maka secara langsung akan berpengaruh terhadap kecepatan gerak (Bernhard, 2010). Peneliti juga meminta kepada siswa untuk membiasakan diri untuk melakukan lari karena dalam lompat jauh kecepatan lari merupakan faktor kunci keberhasilan atlet (Mackenzie, 2005).

Secara lebih rinci, perbaikan yang dilakukan oleh peneliti adalah 1) meningkatkan intensitas dan durasi latihan serta memberikan contoh gerakan yang baik. Selain itu menambah media tali rintangnya. 2) Peneliti memberikan perhatia lebih terhadap 
siswa yang masih belum dapat melakukan lompat jauh dengan maksimal. 3) Guru meminta siswa untuk aktif bertanya atau menyampaikan pendapat agar ditemukan solusi atas permasalahan yang dihadapi siswa. Karena siswa yang berani bertanya akan dapat menyelesaikan masalah yang dihadapinya (Suparsih, 2014). Hasil observasi dan refleksi ini digunakan sebagai acuan dalam memberikan tindakan pada siklus II untuk memecahkan masalah dan mengatasi kendala yang dihadapi siswa dalam melakukan lompat jauh gaya jongkok.

3. Siklus II

Pembelajaran yang dilakukan pada siklus II berjalan dengan baik serta menghasilkan nilai yang memuaskan bagi penelitian ini. Adapun hasil pengamatan yang dilakukan pada siklus II disajikan pada tabel 2 berikut:

Tabel 2. Rekapitulasi Kemampuan Lompat Jauh Gaya Jongkok Siswa Siklus II

\begin{tabular}{ccc}
\hline Ketuntasan & Jumlah Siswa & Persentase \\
\hline Tuntas & 20 & $86.95 \%$ \\
Belum Tuntas & 3 & $13.04 \%$ \\
Jumlah & 23 & $100 \%$ \\
\hline
\end{tabular}

Berdasarkan data yang ditunjukkan pada tabel 2 diketahui bahwa kemampuan siswa dalam melaksanakan lompat jauh gaya jongkok dengan menggunakan media tali rintangan yang diterapkan pada siklus II membuahkan hasil yang memuaskan dimana terdapat 20 siswa yang mampu melaksanakan lompat jauh gaya jongkok dengan baik, hal ini berarti bahwa secara klasikal sebesar $86.95 \%$ sudah mampu melakukan lompat jauh gaya jongkok secara baik. Hasil ini sudah melebihi indikator yang diharapkan yakni $85 \%$. Hasil ini didukung oleh penelitian Gultom (2020) bahwa kemampuan lompat jauh gaya jongkok dapat mengalami peningkatan dengan menggunakan alat bantu tali rintangan.

Peningkatan kemampuan lompat jauh siswa baik pada siklus I terlebih siklus II ditandai dengan peningkatan yang signifikan. Hal ini mengindikasikan bahwa siswa mampu memahami penjelasan guru, mengerahkan kemampuan dengan latihan yang maksimal, serta melakukan dengan penuh keterampilan sesuai dengan latihan yang dilakukan. Sesuai dengan yang dikemukan Azmi (2000) bahwa lompat jauh merupakan gerakan yang diawali dengan berlari untuk melakukan awalan, dilanjutkan dengan menolak dengan tumpuan satu kaki, melayang di udara dan mendarat dengan dua kaki secara bersamaan.

\section{Pembahasan}

Kemampuan siswa dalam melakukan lompat jauh pada kondisi awal sebelum dilakukan tindakan belum begitu baik karena kurang dari setengah dari keseluruhan siswa yang dapat melakukan lompat jauh dengan baik. Selain itu, teknik-teknik dasar dalam melakukan lompat jauh masih belum terlihat baik dimana saat memulai lompatan masih tampak tidak ada persiapan, ketika melompat tidak mendorong badan ke depan, dan saat mendarat ada yang melakukan dengan satu kaki, hal ini selain tidak mendapatkan hasil lompatan yang maksimal juga dapat mengakibatkan cidera jika salah dalam pendaratan.

Pada siklus I sudah terlihat sedikit perbaikan dan peningkatan baik dari teknik lompatan maupun jarak yang ditempuh dalam lompatan yang dilakukan. Hal ini sesuai yang dikemukanan Mardianto (2013) bahwa jika seseorang melakukan lompatan dengan benar dimana seorang melakukan langkah awal dengan benar, melayang diudara dengan benar, dan mendarat dengan benar maka akan menghasilkan lompatan yang jauh.

Pada siklus II pencapaian hasil kemampuan lompat jauh siswa menggunakan tali rintangan sudah mencapai indikator yang diharapkan dimana $86.95 \%$ siswa melakukannya dengan baik. Hasil ini diperoleh karena siswa dilatih untuk terus melakukan 
lompat tali rintangan sesering mungkin, awalan dilakukan dengan kecepatan maksimal, dan gerakan saat melompat dan mendarat dengan kedua tangan diayunkan dari atas ke depan.

Peningakatan kemampuan lompat jauh siswa dari kondisi awal, siklus I, dan siklus II tidak terlepas dari komunikasi antara guru dan siswa serta dorongan motivasi siswa untuk melakukan kegiatan pembelajaran dengan maksimal. Kegiatan fisik perlu selalu dilatih agar mendapatkan hasil yang terbaik, tugas guru mengarahkan dan mengoreksi segala kegiatan yang dilakukan oleh siswa agar mendapat hasil sesuai dengan yang diharapkan.

\section{KESIMPULAN DAN REKOMENDASI}

Berdasarkan hasil dan pembahasan penelitian yang dilakukan di atas, dapat ditarik kesimpulan bahwa kemampuan lompat jauh gaya jongkok dapat ditingkatkan melalui media tali rintangan. Peningkatan tersebut dapat dilihat dari kemampuan siswa secara klasikal dalam melakukan lompat jauh gaya jongkok pada siklus I adalah 17 siswa atau sebesar $73.91 \%$ menjadi $86.95 \%$ atau sebanyak 20 siswa yang mampu melakukan lompat jauh gaya jongkok dengan baik.

Berdasarkan kendala yang dihadapi selama penelitian maka dapat direkomendasikan agar penelitian selanjutnya dapat memberikan beberapa variasi dalam latihan agar siswa lebih terampil dan memiliki kekuatan otot sehingga daya dorong atau daya ledak lebih kuat dalam mendorong lompatan siswa. Guru juga dapat memberikan variasi kegiatan belajar seperti membuat turnamen atau memberikan hadiah bagi siswa terbaik dalam melakukan kegiatan pembelajaran.

\section{DAFTAR PUSTAKA}

Admojo, T, D. (2018). Upaya Meningkatkan Kemampuan Lompat Jauh Gaya Jongkok Menggunakan Modifikasi Alat pada Siswa Kelas V SD Sumberurip I Brebek Kecamatan Brebek Kabupaten Nganjuk Tahun 2016. Simki-Techsain, 2 (4), 1-11.
Arikunto, S. (2014). Prosedur Penelitian Suatu Pendekatan Praktik. Jakarta: Rineka Cipta.

Azhar. (2015). Pengaruh Latihan Lompat, Jingkat dan Langkah Terhadap Hasil Lompat Jauh Siswa SMP Negeri 1 Peusangan Kabupaten Bireun. Jurnal Administrasi Pendidikan, 3 (1), 68-83.

Azmi, C, H. (2000). Metode Latihan Lompat Jauh. Journal Iptek Olahraga, 2 (1)

Bernard, A. (2010). Asthma and Swimming: Weighing the Benefit and the Risks. Journal de Pediatria, 86, 171-182.

Gultom, D. (2020). Meningkatkan Kemampuan Teknik Lompat Jauh Gaya Jongkok dengan Menggunakan Alat Bantu Tali Rintangan di Kelas VII-3 SMP Negeri 1 Patumbak Tahun Pelajaran 2018/2019. Jurnal Ansiru PAI, 4 (2), 184-190.

Hanief, Y, N., dan Sugito, S. (2015). Membentuk Gerak Dasar pada Siswa Sekolah Dasar Melalui Permainan Tradisional. Jurnal SPORTIF: Jurnal Penelitian Pembelajaran, 1 (1), 100113.

Haryono, D. (2018). Meningkatkan Kemampuan Teknik Lompat Jauh Gaya Jongkok dengan Menggunakan Alat Bantu Tali Rintangan. Jurnal Wahana Pendidikan, 5 (1), 1-9.

Hasibuan, R. (2014). Upaya Meningkatkan Hasil Belajar Lompat Jauh Melalui Pembelajaran Media Rintangan pada Siswa Kelas XI SMA Swasta 1 Kabanjahe Kabupaten Karo. Jurnal Pengabdian Kepada Masyarakat, 20 (77), 1-8.

Makenzie, B. (2005). 101 Evaluation Test. Electric World plc. London.

Mardianto, M, I. (2013). Peningkatan Hasil Belajar Lompat Jauh Melalui Pendekatan Pembelajaran Bermain Loncat Katak pada Siswa Kelas 5 SDN Duwet Kota Pekalongan. Jornal of Phyisical Education, Sport, Health and Recreatios, 2 (12), 749-758.

Nur, A. (2019). Pengaruh Latihan Lompat Rintangan Terhadap Kemampuan 
Lompat Jauh Gaya Jongkok pada Siswa Putra SMP Negeri 1 Luwuk. Jurnal Pendidikan Olahraga, 9 (1), 18.

Ridwan, M. (2020). Pelatihan Lari Lompat Rintangan Setinggi $50 \mathrm{~cm}$ Lima Repetisi Tiga Set dalam Meningkatkan Jarak Lompatan Nomor Lompat. Journal of Classroom Action Research, 2 (1), 63-69.
Satriyo, D. (2014). Pembelajaran Lompat Jauh Menggunakan Rintangan Tali Meningkatkan Hasil Belajar Lompat Jauh Gaya Jongkok. Journal of Physical Education, Sport, Health and Recreations, 3 (5), 1084-1092.

Suparsih. (2014). Upaya Meningkatkan Keberanian Bertanya pada Materi Luas dan Volume Kubus dan Balok dengan Penemuan Terbimbing. Jurnal Derivat, 1 (2), 30-38. 